Oñati Socio-legal Series, v. 8, n. 2 (2018) - Critical Prison Studies, Carceral Ethnography, and Human Rights: From Lived Experience to Global Action ISSN: 2079-5971

\title{
The International Persistence and Resilience of Solitary Confinement
}

Reiter, K., 2018. The International Persistence and Resilience of Solitary Confinement. Oñati Socio-legal Series [online], 8 (2), 247-266. Received: 28-12-2016; Accepted: 0206-2017. Available from: https://doi.org/10.35295/osls.iisl/0000-0000-0000-0930

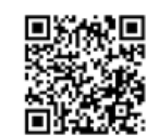

\begin{abstract}
Drawing on a combination of legal analysis and fieldwork conducted with prisoners and administrators in both Denmark and the United States, this article interrogates how solitary confinement has been defined and constrained - or not - in the context of U.S., European, and international law over time. Solitary confinement has been pervasive in prisons across the world, since the first prisons opened. And solitary confinement has been surprisingly predictable over its long history, producing instances of extreme and de-humanizing brutality, inspiring ongoing debates about just how psychologically detrimental the practice is, and persistently resisting critiques based on evidence of brutality and psychological damage. The pervasiveness and predictability of solitary confinement suggests substantial limitations inherent in the newest barrage of critiques leveled by courts, scholars, international human rights bodies, and professional associations against the practice. Indeed, many critiques of solitary confinement have failed because they have promoted reformist rather than non-reformist (or abolition) agendas - a distinction articulated by Mathiesen (1974/2014).
\end{abstract}

\section{Key words}

Solitary confinement; human rights; incarceration; legal reform

\section{Resumen}

Partiendo de una combinación de análisis de leyes y trabajo de campo, este artículo investiga cómo se ha definido y limitado -o no- el régimen de aislamiento en los códigos legales. El aislamiento carcelario ha sido una constante en todo el mundo, produciendo ejemplos de brutalidad extrema, suscitando discusiones sobre su

\footnotetext{
Thanks to Sarah Turnbull, Debra Parkes, Joane Martel, and Dawn Moore for inviting me to join an inspiring group of scholars at the Oñati Institute in the Summer of 2016, to the scholars at the Institute (especially Bree Carlton) for helpful critical engagement with this piece, to Jennifer Sumner and Lori Sexton for their ongoing collaboration in research work in Denmark, and to Ashley Rubin and the anonymous reviewers for pushing me to strengthen the structure and contribution of the argument. The Denmark research described herein was supported by the National Science Foundation under Grant No. 1455971.

* Keramet Reiter is an assistant professor in the Department of Criminology, Law and Society and at the School of Law at the University of California, Irvine, CA 92697. She is the author of 23/7: Pelican Bay Prison and the Rise of Long-Term Solitary Confinement (Yale University Press 2016) and Mass Incarceration (Oxford University Press 2017) and has recently published articles in Law and Society Review, Law and Social Inquiry, and Punishment \& Society. Email address: reiterk@uci.edu.
} 
impacto psicológico y eludiendo las críticas fundadas en pruebas. La ininterrupción y predecibilidad del aislamiento carcelario indican que hay limitaciones sustanciales en la nueva ola de críticas por parte de juzgados, académicos, organizaciones de derechos humanos y asociaciones profesionales. Lo cierto es que muchas de las críticas han errado porque han promovido la reforma en lugar de la abolición, distinción explicada por Mathiesen (1974/2014).

Palabras clave

Aislamiento carcelario; derechos humanos; encarcelamiento; reforma jurídica 


\section{Table of contents / Í ndice}

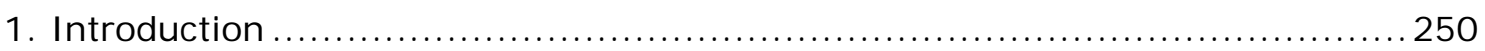

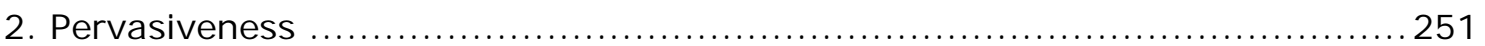

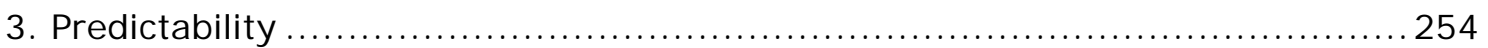

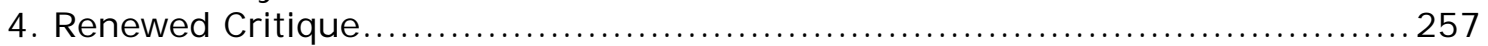

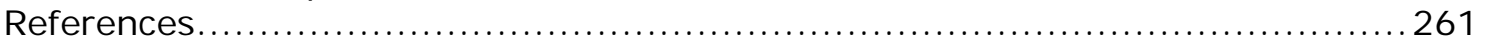




\section{I ntroduction}

As a scholar of prisons who is particularly interested in the physical and administrative infrastructure of facilities built to incarcerate, I frequently seek out opportunities to visit prisons: to interview prisoners and staff for research, or to take criminology students on prison tours for the educational experience. ${ }^{1}$ The thing on any prison visit I always look for - and explicitly ask to see - is the isolation cell: the dark cell at Alcatraz, the death row segregation unit at San Quentin, the restraint room in the otherwise-notoriously humane Danish prisons. In the room where the worst thing happens to the worst prisoner, competing purposes of punishment collide, rules are suspended, ethics evaporate, and the everyday harsh reality of incarceration becomes the most real. This is true of the abandoned dungeons in the former U.S. federal prison on Alcatraz Island (in California), true of the highest security state and federal supermaxes in the United States, and, it turns out, true of restraint rooms in Danish prisons.

Still, the first restraint room I saw on one of my first visits to a Danish prison surprised me. It surprised me more, in fact, than anything I had seen on dozens of American prison tours. In Denmark, I first was stunned by the openness - in every sense of the word - of the country's prisons. Prison officials welcomed me, a young foreign scholar, into any facility I could find my way to, showed me every nook and cranny, let me walk around freely, with my cell phone and laptop sticking out of my shoulder bag, and talk to whomever I wished. And of course, many of the facilities literally had no fences. Mølgelkær, one of the country's open prisons, looked more like a college campus - a series of cabin-like dorm, workshop, and classroom buildings surrounding a lush grassy green. In light of this, the restraint room in a closed prison just a few miles from the open Møgelkær prison was all the more surprising.

I knew there was a long history of using solitary confinement in Denmark, both preand post-conviction (Reiter 2014, Smith 2017). But standing under the flickering fluorescent lights in that restraint room, I experienced not history, but everyday reality. Here are my field notes describing the place:

[I]t was also in this building where we saw the isolation wing, which was definitely the most memorable part of the tour. The most memorable thing was seeing the room with the restraint bed, which looked eerily like a lethal injection table. The room was distinctively lit with yellow lights. The bed was bolted to the floor. There was nothing else in the room. I asked how long a prisoner might be kept there, and [the prison officer] said maybe as long as 24 hours (...). I asked about how they would be fed; she said they might be given water, and the lights could be dimmed for sleeping. (Field Notes, 24 Aug 2011)

Twenty-four hours in restraints? The U.S. National Commission on Correctional Healthcare limits orders for clinical restraint or seclusion to 12 hours, with required checks every 15 minutes (Champion 2007, p. 428). Of course, these rules are not always followed, and instances of people dying in restraints in the United States are legion. $^{2}$

Four years later, I would return to that same prison, where I happened to interview a prisoner who had passed out on that very restraint bed. The prisoner explained his harsh treatment at the hands of the guards, why he was pummeled and then pushed into restraints: "Then they was after me. Because they have three guards with them and police. And I escaped anyway. So, then they was very mad" (interview with

\footnotetext{
${ }^{1}$ I acknowledge here the vibrant debate in the punishment literature about whether such tours are ever ethical. See, e.g., Piché and Walby 2010, 2012, as well as Adams 2001, Brown 2009 and Dey 2009. For a brief rebuttal of this argument, especially as it relates to research, see Reiter et al. 2017.

${ }^{2}$ A simple Google search for restraint deaths in prisons yields a disturbing 17,000 results. A 2015 Human Rights Watch report detailed the abusive uses of restraint chairs across the United States in prisons from South Carolina to Pennsylvania to Michigan (Fellner 2015). In Denmark, the Danish Institute against Torture (DIGNITY) has reported to the United Nations that, between 2005 and 2015, the use of fixation or restraints, in security cells, increased by 43 percent (Rytter 2015).
} 
prisoner, $29 \mathrm{Jul} 2015)$. This particular prisoner implicitly acknowledged his status as the worst of the worst: he had escaped in spite of concerted attempts to stop him. The prisoner understood that he had challenged the efficacy of the system, and he explained his treatment as an unsurprising and rational response to his actions.

Both the pervasiveness and the rationality (as well as the predictability) of solitary confinement are often overlooked, especially in critiques of the practice, which tend to use terms like "aberrant" or "excessive", and to focus on one or two horror stories of abuse, instances when things accidentally spun out of control, as in the case of the pummeled Danish prisoner, or in the cases of U.S. prisoners who have been severely scalded in boiling hot showers after smearing themselves in their own feces during extended periods of time in solitary confinement (Press 2016, Reiter 2016). In an era in which solitary confinement, segregation, and supermaxes face a renewed round of scrutiny and critique, the question of whether isolation practices are anomalous or not gets drowned out by the chorus of people detailing a litany of abuses, too extreme to be digested as either pervasive, rational, or predictable. But the existence of solitary confinement in prison systems across the world, including two systems as disparate as the United States and Denmark, provides a starting point for thinking about the implications of the pervasiveness and predictability of the practice.

Solitary confinement has been pervasive both in terms of its historical longevity and its geographic ubiquity. And solitary confinement has been predictable in terms of its institutional effects and outcomes: solitarily confined prisoners (like the pummeled Danish prisoner and the scalded American prisoners) frequently experience abuse at the hands of guards, and at least some prisoners experience detrimental physical and mental health consequences as a result of their solitary confinement. Despite extensive documentation of both its misuse and detrimental effects, however, the institution of solitary confinement resists, and quickly rebounds from, these critiques. The pervasiveness and predictability of solitary confinement, respectively, are the subjects of the next two sections.

The history of the pervasiveness and predictability of solitary confinement reveals, in turn, the persistence and resilience of the practice over time. The newest barrage of critiques leveled by courts, scholars, international human rights bodies, and professional associations against the practice of solitary confinement, then, risk being limited in their impact. Without acknowledging and engaging the failures of prior reform efforts, current efforts risk having limited long-term effects (see also Rubin and Reiter 2017).

Arguably, many earlier critiques of solitary confinement have failed because they have promoted reformist rather than non-reformist agendas - a distinction articulated by Mathiesen (1974/2014). Specifically, "reformist" agendas legitimize existing systems through positive reforms, while "non-reformist" agendas seek to abolish the existing system through negative reforms (Id.). In the case of solitary confinement policies and practices, reformers have focused on aberrant cases of abuse, on protecting vulnerable prisoners, or on mitigating harsh conditions. Such positive, reformist agendas have, I argue, contributed to the persistence of solitary confinement, notwithstanding the abuses and dangers inherent to the practice. Indeed, this analysis of the pervasiveness and predictability of solitary confinement suggests that the practice seems likely to survive as long as reformist agendas take precedence over non-reformist (or abolitionist) strategies.

\section{Pervasiveness}

Solitary confinement has existed since the first prisons were built in the United States, in the late eighteenth century, and as I learned in my research in Scandinavia, it exists even in the reputedly most humane prisons in the world, in Denmark and Norway, for instance. The pervasiveness of the practice - across both time and geography - is not always obvious, but nonetheless seems especially important to 
posit and interrogate in an era of renewed attention to potential reforms to the practice.

As Smith has noted, "a belief in the ability to rehabilitate criminals through the use of isolation regimes became a cornerstone" of the "modern prison system" that developed in Europe in the late eighteenth century and in the United States in the early nineteenth century (Smith 2009, p. 3). In the United States, the Pennsylvania model, which maintained prisoners in "large-scale solitary confinement," competed for viability with the Auburn model, which permitted prisoners to work together in congregate labor, but required them to remain silence (Smith 2009, Rubin 2015). The split between the Auburn model and the Pennsylvania model was the first in a long line of variations in the forms of isolation imposed on prisoners by prison officials.

The Pennsylvania model of large-scale solitary confinement quickly became popular in Europe. Johnston (2000) and Smith (2009) have traced its spread across Europe to Belgium, Denmark, England, France, Germany, Holland, Norway, and Sweden, and even further afield to Chile and New Zealand. In sum, from the time the first prisons were built in the United States, and elsewhere across the world, in the late eighteenth and early nineteenth centuries, solitary confinement was an integral part of incarceration.

However, as the institution of the prison spread from state to state across the United States, and became more established elsewhere in the world, the practice of solitary confinement faced frequent scrutiny (Beaumont and Tocqueville 1833, p. 41, Dickens 1842, O'Donnell 2014, pp. 45-47). Due in part to widespread criticisms about the health dangers, the cruelness, and the inhumanity of the solitary confinement imposed through the Pennsylvania model, the Auburn model of congregate (if silent) labor became the dominant incarceration model in the United States within a few decades of the country's founding (Rubin 2015, p. 388). Solitary confinement seemed to be falling out of favor.

Still, Eastern State Penitentiary continued to use the Pennsylvania model of solitary confinement until 1913 (and continued to operate late into the twentieth century), in spite of the criticisms of the likes of Beaumont, Tocqueville and Dickens. And even as the Auburn model of congregate labor gained prominence, prisons across the United States continued to use some form of solitary confinement. An 1890 Supreme Court decision provides especially revealing evidence of this. In the case of In re Medley, the U.S. Supreme Court condemned Colorado officials for initiating a new practice of keeping death-sentenced prisoners in solitary confinement. The Court famously declared long-term solitary confinement in prisons to be a barbaric practice of the past, noting that in prior experiments with the practice: "A considerable number of the prisoners fell, after even a short confinement, into a semi-fatuous condition (...) and others became violently insane; others, still, committed suicide; while those who stood the ordeal better were not generally reformed, and in most cases did not recover sufficient mental activity to be of any subsequent service to the community" (In Re Medley 1890, at 168). Despite this condemnation of Colorado's use of solitary confinement, the practice persisted.

By 1890, there was only one Pennsylvania model prison (Eastern State) maintaining an entire institution full of prisoners in long-term solitary confinement, but most prisons maintained small blocks of isolation cells, often dubbed the hole, for at least short-term disciplinary purposes, segregating prisoners for up to 30 days at a time (Reiter 2012). For instance, the warden of Alcatraz, a federal prison that operated from 1934 through 1963, used the Spanish dungeons, for a few days at a time, to manage the worst prisoners (Odier 1982, p. 117). And from the mid-1950s, California's San Quentin State prison, which housed the state's death row, had an infamous adjustment center for the temporary, punitive isolation of death row prisoners in solitary confinement (Haney and Lynch 1997, p. 489). By the 1970s, these shorter-term forms of isolation were again facing public scrutiny from U.S. 
courts. Throughout the 1970s, U.S. courts acknowledged - and attempted to constrain - temporary uses of solitary confinement in places like San Quentin's Adjustment Center (Id.). But no court ordered the total elimination of solitary confinement.

Indeed, solitary confinement continued to be used - in prisons across the United States and the world. Smith (2009) notes that the Pennsylvania model of solitary confinement persisted in Scandinavian prison systems, especially, well into the twentieth century. And O'Hearn (2013) describes experiments with "cellular isolation", similar to the conditions in San Quentin's Adjustment Center, in both I reland and Turkey over the course of the second half of the twentieth century. In prisons across the world, as in Denmark and the United States, solitary confinement has been an integral part of prisons since the first physical prisons were built in the eighteenth century, if not earlier.

In the late twentieth century, the exact form of solitary confinement has changed again, with states across the U.S. opening technologically advanced super-structures designed to concentrate the worst of the worst prisoners in isolation facilities semipermanently. These facilities, known as supermaxes, tend to be better lit, cleaner, and better operationally organized than the torturous dark holes that were the subject of litigation across the United States in the 1970s. Nonetheless, as discussed in the next section, abuse and psychological trauma, similar to that documented at Eastern State Penitentiary in the 1800s, has also been documented in these more modern facilities.

Again, this newest form of solitary confinement has not been restricted to the United States. Supermaxes have spread across the globe - not only through the influence of the U.S. military in military prisons in Guantanámo, Cuba, Abu Ghraib, Iraq, and other unidentified black sites - but through an increasingly international shared culture of corrections in which other nations look to the United States as a model for prison structure and policy. In one of the few books to examine the phenomenon of the supermax from a global perspective, Ross's (2013) The Globalization of Supermax Prisons contains chapters detailing how both New Zealand and South Africa copied the U.S. supermax prison model. Carlton (2007) has described the ongoing use of solitary confinement, especially in concentrated supermax-like facilities in Australian prisons over the twentieth century. In Denmark, which opened one high-security prison equipped with semi-permanent isolation wings in 2006 , and which opened a second such facility in 2017, prison officials point not to the United States but to Canada for their inspiration for prison structure and policy (interview with prison planning director and prison architect, 10 Aug. 2015; interview with the Deputy Director General, 21 Jul. 2015). Canada, however, has imported more than a few prison policies from the United States, and a few of the design elements in modern Danish prisons, like perforated steel plates covering doors and windows, eerily echo design elements developed in U.S. supermaxes (Reiter and Koenig 2015).

One interpretation of this history of solitary confinement is that the practice has been so varied - in terms of physical structures, durations of confinement, and articulated purposes - that it could hardly be called either consistent or pervasive. Another interpretation, however, is that solitary confinement existed in the very first penitentiaries in the United States, and, regardless of ongoing criticism from prisoners, visitors, public intellectuals, and lawyers, solitary confinement has continued to exist, in penitentiaries and prisons across the United States (Rubin and Reiter 2017) and, even, across the world. If solitary confinement has faced scrutiny since it was first initiated in Pennsylvania's Eastern State Penitentiary in the nineteenth century, and yet continued to exist, what will make the newest round of national and international criticism focusing on solitary confinement any more likely to eliminate, or even fundamentally reform the practice? 


\section{Predictability}

Not only has some form of solitary confinement existed since the first prisons were built in the United States and Europe, but certain aspects of the practice have been surprisingly predictable. Identifying the characteristics and mechanisms of this predictability reveals the potential shortcomings of current (and future) critiques of solitary confinement. First, solitary confinement produces contentious relationships between prisoners and guards, frequently resulting in abuses of prisoners in isolation, though such abuses are not systematically tracked. Second, some prisoners have become extremely ill in isolation after only a few weeks, while others have survived years in isolation with their minds and bodies apparently intact. The co-existence of these two populations has produced persistently unresolved debates about whether solitary confinement is dangerous for human beings subject to it. Third, both the abuses of prisoners in solitary confinement and the debates over the short- and longterm health consequences of solitary confinement have inspired critique and reform attempts. But the practice of solitary confinement has persisted, seemingly impervious to criticism.

Many prisoners experience serious abuses in isolation. These abuses are most often reported in the media as tragic, idiosyncratic stories, like those of Darren Rainey and Vaughn Dortch. Rainey smeared himself in feces. Guards dragged him into a hot shower, and left him there. He was scalded to death (Press 2016). But that only happened once. Or did it? The exact same thing happened in a California isolation facility two decades earlier, only the prisoner, Dortch, whose skin peeled off in chunks, survived to tell his story (Reiter 2016). Then there was Kalief Browder, who was held for three years in solitary confinement on Rikers I sland jail in New York, before being released without ever even facing criminal charges (Gonnerman 2014). He committed suicide two years later, using strips of bed sheets, a technique he first attempted on Rikers Island; he had been brutally beaten following this earlier suicide attempt (Gonnerman 2016).

SolitaryWatch, which tracks these kinds of stories across the United States, recently reported another tragic death:

One such story was that of J erome Laudman, who in 2008 was found lying face-down in a pile of feces and vomit alongside moldy food trays. He was naked and unresponsive, and for eleven days guards refused to enter the cold, smelly cell. They later instructed two other prisoners to remove him, and he was transferred to a hospital where his body temperature indicated hypothermia. He died of a heart attack soon after. Laudman's story was one of many shared during the proceedings [in a class action lawsuit between the South Carolina-based Protection and Advocacy for People with Disabilities Inc (P\&A) and the South Carolina Department of Corrections]. (Blatt-Herold 2016)

This story rightly points out that Laudman's abuse and death was "one of many". How many is impossible to know, as the United States tracks deaths in custody, but the exact cause of death is difficult to identify.

Of the four cases of abuse detailed here, only two involved a death in custody. The other two (Dortch and Browder) involved egregious abuse in custody - with facts that were persistently contested until investigative journalists took specific interest in each case (Sixty Minutes in the case of Dortch and a New Yorker staffer in the case of Browder). This interest, in turn, brought the cases to the attention of courts; the Dortch case was mentioned in the California litigation about conditions in supermaxes (in Madrid v. Gomez in 1995), and the Browder case was mentioned by Justice Kennedy in a concurrence condemning long-term solitary confinement (in Davis $\mathrm{v}$. Ayala in 2014). The fact that only a few of these stories of abuse make national media headlines too readily masks the frequency with such abuse occurs.

These stories tend to inspire easy solutions: keep the mentally ill (who might smear themselves in feces) out of solitary confinement; keep juveniles (who might be susceptible to suicide) out of solitary confinement; train the guards better. Indeed, 
each case became part of a larger lawsuit or legal reform effort, which challenged conditions of confinement for similarly situated young and mentally ill prisoners in long-term solitary confinement. Many such reforms seek to create protected categories of prisoners: the youth, the mentally ill, or even pregnant women. For instance, in the Madrid (1995) case, Judge Henderson, who oversaw years of litigation and monitoring of California's main supermax prison, prohibited seriously mentally ill prisoners, like Vaughn Dortch, from being placed in solitary confinement at the Pelican Bay supermax (Madrid v. Gomez 1995). And New York City and the state of New York, following Kalief Browder's suicide have both implemented reforms to exclude juveniles and those with mental and developmental disabilities from solitary confinement (Rakia 2015, Peoples v. Fischer 2016). In other words, reform efforts tend to respond directly to the specific details of individual, horrific stories of abuse, rather than acknowledging the pervasiveness and predictability of egregious abuses, regardless of individual circumstances of youth or mental illness, in any and all solitary confinement units, across time and geography.

Moreover, reform efforts targeting protected categories like the young, or the mentally ill, or more recently, pregnant women, leave behind a core of people who are not young, not (yet) mentally ill, not pregnant, and therefore not deserving of protection. This durable core of punishable subjects becomes an ongoing justification for the need for solitary confinement (see also Reiter and Blair 2015). Meanwhile, those who are excluded from solitary confinement experience not just protection, but also labeling as weak and vulnerable, which in turn perpetuates destructive stereotypes about age, gender, and mental ability. Indeed, in other contexts in which protected categories of vulnerable subjects have been carved out and then exempted from harsh punishments, including exemptions from the death penalty and sentences to life without parole for certain vulnerable sub-populations, scholars have criticized the exemptions as encouraging and perpetuating destructive stereotypes about mental disability (Blume et al. 2008, Pifer 2016), and as inadvertently producing harsher sentences for those prisoners deemed vulnerable and deserving of protections (Gottschalk 2014). In sum, many attempts to improve conditions of confinement in solitary, or to limit its imposition on some vulnerable groups, have been positive, reformist efforts, ultimately bolstering the legitimacy of the existing system, rather than negative, non-reformist or abolitionist, efforts, with the potential to challenge the legitimacy of systems of solitary confinement.

Although some solitary confinement reformers have sought to protect vulnerable groups of people from isolation, others have argued that, not just children or the mentally ill, but everyone is vulnerable to the harms of solitary confinement. Indeed, one of the most persistent criticisms leveled against the practice of solitary confinement - a criticism that tends to suggest the practice of solitary confinement should be abolished rather than reformed - is that human beings literally lose their minds in solitary confinement.

This kind of critique of solitary confinement is as timeless as the practice itself, dating back to the first isolation prison in the United States (Eastern State Penitentiary) and England (Pentonville) [O'Donnell 2014]. French political theorists Beaumont and Tocqueville (1833, p. 41) criticized the practice of solitary confinement in the United States as early as 1833 , noting it "devours the victim incessantly and unmercifully". A decade later, Dickens (1842) famously visited the original Pennsylvania model prison, Eastern State Penitentiary, the first long-term, concentrated solitary confinement facility in the United States, and condemned the place as nightmarish, inflicting a mental pain "worse than any torture of the body". More recent scholarship has argued that Dickens's experience in the prison was limited, and colored by a conversation with one manipulative prisoner (O'Donnell 2014, pp. 45-47), but few dispute the premise that solitary confinement can be and often is dangerous for human beings, whose very existence presupposes interaction with other human beings (Guenther 2013). Perhaps the most consistent and predictable characteristic 
of solitary confinement over time and across disparate geographies is the perpetual criticism the practice has faced, since its very first use.

The critiques, then, persisted into the twentieth century. In the 1950s, researchers experimenting with the effects of sensory deprivation on college students and prisoners of war noted that hallucinations could be induced with just a few hours of sensory deprivation or total isolation (Brown and Milner 2003). During the 1970s, prisoners across the country successfully litigated harsh conditions of confinement. In many of these cases, the constitutionality of solitary confinement, or the hole, was frequently challenged. Prisoners described the harsh conditions in isolation units dark, filthy cells where they languished without food or contact for days, if not weeks, at a time - in states like Arkansas, Ohio, Alabama, Colorado, and Pennsylvania (Reiter 2012). Just as for the Supreme Court judges in Medley in 1890, state court judges hearing descriptions of these conditions were appalled. They described the conditions as "torture", "cruel" and "unusual", and ordered reforms to make isolation cleaner, brighter, and more spacious (Id.).

Lawyers challenging the most modern iteration of solitary confinement, the supermax prison, have raised similar critiques, documenting how prisoners with mental illness are both at greater risk of ending up in solitary confinement and of further deteriorating while isolated (see, e.g., Madrid v. Gomez 1995, Silverstein v. Federal Bureau of Prisons 2014). In a survey of the literature written in 1997, Haney and Lynch, both psychologists by training, noted the robust body of research data documenting the detrimental mental health consequences of solitary confinement for human beings. More recently, medical doctors have joined the chorus criticizing solitary confinement, arguing that lack of human contact not only has psychological consequences, but physical ones as well - ranging from elevated risks of heart attack to loss of spatial reasoning abilities and experiences of physical pain (Ashker v. Brown 2015, see also expert reports by Lieberman 2015, Keltner 2015, Hawkley 2015).

But for every critique of the detrimental health consequences of isolation, there have been an equal number of defenders arguing that the risks are over-stated. These defenders range from the theoretical to the empirical. In Prisoners, Solitude and Time, O'Donnell (2014, pp. 271-275) argued that some of the detrimental consequences of solitary confinement (like those described by Dickens after his visit to Eastern State Penitentiary) have been overstated, while many of the potentially positive consequences (a sense of accomplishment, mindfulness, and personal growth) have been understated or ignored. Just a few years earlier, a group of researchers published a study of the effects of solitary confinement on state prisoners in Colorado, and found limited evidence of psychological deterioration in solitary confinement (O'Keefe et al. 2011). Scholars of solitary confinement, however, have criticized that Colorado Study for a biased experimental design, flawed implementation, and selective exclusion of some outcomes, including a participant suicide (see, e.g., Grassian 2010 and The Major Methodological Flaws in the 'Colorado Study', by Craig Haney, memorandum on file with the author).

Just as the dangers of the lived experience of solitary confinement have been debated, so have the long-term consequences of the experience been debated. O'Donnell (2014) has argued that many of the worst symptoms of solitary confinement abate when the confinement ends, and I myself have written about the remarkable ability of some prisoners to overcome the trauma of isolation (Reiter 2016). The debate over just how damaging solitary confinement is remains unresolved.

And the practice persists, remarkably resilient to criticism. Although solitary confinement has changed in form in response to public or legal critique, it has never completely disappeared. Two examples of such form changes, again drawn from United States and Denmark, are particularly revealing. In the United States during the 1970s, prisoners across the country brought legal challenges in federal courts to the conditions of their confinement. The rash of litigation resulted from a series of 
legal changes, which provided prisoners with more opportunities to raise constitutional objections to the conditions of their confinement, which in turn were part of a larger "rights revolution" that took place in U.S. courts in the 1960s (Friedman 1993, Feely and Rubin 1998). By 1975, more than 30 jurisdictions had at least one prison that had been declared unconstitutional (Feeley and Rubin 1998, p. 40 ). Of the dozens of cases about prison conditions litigated during this period, most at least mentioned conditions in solitary confinement (as well as conditions in isolation, where multiple prisoners were segregated together in one, dark, overcrowded cell for days at a time). In an earlier article, I described how prison officials' responses to this litigation tended to disaggregate rights from privileges: institutionalizing minimum rights, like adequate lighting and an hour per day out of the cell, but eliminating all privileges, like comfortable bedding and visits with family members (Reiter 2012, pp. 107-108). Within a few years, prison officials were building supermax prisons, newly designed to exactly the minimum standards for space, light, and hygiene courts had established in the 1970s litigations (Id.).

In Denmark, in the late 1990s, pre-trial remand facilities, which have historically imposed solitary confinement on all prisoners awaiting sentencing, faced significant "international criticism" from multiple human rights bodies (Smith 2011, p. 48). As a result of this sustained criticism, Danish prison officials have worked to reduce the use of pre-trial solitary confinement, and official Danish Prison Service Statistics report that fewer than one percent of remand prisoners today are in solitary confinement (Smith 2017). This is a stark contrast with the nearly half (more than 40 percent) of all remand prisoners who were in solitary confinement in the late 1970s and early 1980s. In practice, however, Smith, who has studied these practices extensively, describes how many Danish remand prisoners remain in conditions that are functionally similar to those that have been criticized over the past few decades: spending 23 hours a day in their cells alone. Smith explains that few programs - such as work or education - exist in remand facilities, and the physical structures favor isolation, not socialization (Id.).

These two examples reveal what I argue is a predictable pattern not just in the abusive and dangerous effects of solitary confinement, but in attempts to ameliorate these effects: solitary confinement as a practice is remarkably resistant to reform. The major form this resistance (or resilience) has taken is the tweaking of operational and design details: changing the sizes of cells or durations of confinement, altering the extent and nature of human contact, or re-articulating new purpose of the practice. Such adjustments tend to conceal the pervasiveness and persistence of the practice of separating some prisoners from the majority of human contact for extended periods of time. Many of these legal and institutional modifications to conditions of solitary confinement amount to positive, "reformist" reforms to the existing system of solitary confinement, rather than negative, "non-reformist" abolition of the existing system (Mathiesen 1974/2014).

The very predictability of solitary confinement - its resilience as a correctional practice in the face of criticism, the chronically unresolved debates over just how bad isolation is for human beings, and repeated instances of de-humanizing brutality suggest the importance of understanding both the history and the context in which solitary confinement is imposed. Understanding the predictability and resilience of the practice, in turn, provides a critical framework within which to analyze the current era of renewed critiques of the practice - critiques which integrate a blend of reformist and abolitionist agendas.

\section{Renewed Critique}

While the United States has an estimated 20,000 to 80,000 prisoners in long-term solitary confinement and tens-of-thousands more in shorter-term solitary confinement (Baumgartel et al. 2015, Beck 2015), recent decisions from various European courts and human rights bodies suggests that the United States is not alone 
in imposing this practice. In recent years, as the use of solitary confinement has expanded in the United States, in supermax facilities (Gibbons and Katzenbach 2006, Shames et al. 2015, and arguably across the globe (Ross 2013, criticisms of the practice have swelled again, too. Critiques of solitary confinement have escalated in countries as notoriously humane and transparent as Denmark and Norway, as well as in countries with longer records of opacity and abuse in how prisoners are treated, like the United States. Investigative reporters, civil rights advocates, professional associations, judges, and international human rights bodies have all joined the chorus of critics,

In the 2010s, several high-profile legal decisions across the world have condemned the practice of long-term solitary confinement. First, in 2012, in Ahmad v. the United Kingdom, the European Court of Human Rights criticized U.S. solitary confinement policies. In Ahmad, the United States sought the extradition of Babar Ahmad, an alleged terrorist, from the United Kingdom; Ahmad raised the question of whether his extradition should be precluded under international law because of the high likelihood he would be placed in the U.S. federal supermax, ADX in Florence, Colorado, which would constitute cruel, inhuman and degrading treatment, in violation of the Convention Against Torture. The European Court of Human Rights ultimately ruled that Ahmad could be extradited, but not without a careful and critical review of U.S. supermax policies and practices.

In 2014, U.S. Supreme Court Justice Kennedy, who is known for his willingness to reference international law and human rights standards (McCaffrey 2013), implicitly echoed some of the European Court of Human Rights' Concerns, as stated in Ahmad in 2012. Specifically, Kennedy wrote an unusual concurrence in the death penalty case of Hector Ayala. Although Kennedy agreed with the Court's decision to uphold Ayala's death sentence, Kennedy wrote to condemn the conditions of Ayala's longterm solitary confinement, and explicitly invited a challenge to such practices (Davis v. Ayala 2014).

J ust one year later, in 2015, the High Court of I reland refused to extradite an alleged terrorist to the United States, noting the European Court of Human Rights' 2012 findings in Ahmad and "respectfully disagreeing" with the court's findings that confinement in the U.S. federal supermax at ADX did not constitute cruel, inhuman and degrading treatment. The court concluded firmly that: "being denied the opportunity for meaningful contact with others, the prisoner in solitary confinement is prevented from being fully human. To prevent another from being fully human is by definition inhuman and degrading treatment" (Attorney General v. Damache 2015, para. 11.11.12).

In 2016, in Breivik v. State, the Oslo District Court ruled that Anders Breivik, who killed 77 people in a car bomb detonation and shooting spree in Norway in 2011, had inadequate human contact in solitary confinement in the Skien prison, where he is serving the maximum sentence of 21 years. According to the court, this lack of human contact constituted cruel and degrading treatment (Henley 2016).

Leading jurists in Europe and the United States, then, have firmly condemned the practice of solitary confinement in recent years. In these cases, the courts integrated individual stories of experiences of isolation with critiques of the practice and calls for its limitation and mitigation. And the cases tended to assume that isolation can and does have detrimental mental health consequences. None, however, mentioned the predictable and persistent resilience of the practice of solitary confinement in the face of exactly the kind of critiques being raised in AG v. Damache 2013, Davis v. Ayala 2014, and Breivik v. State 2016.

The judicial decisions echo statements made by various international human rights bodies, condemning the practice of long-term solitary confinement, and calling for limitations on its use. In addition to the UN Convention on Civil and Political Rights (ICCPR) and the Convention Against Torture (CAT), which have both forbidden cruel, 
inhuman and degrading treatment since the 1990s (Smith 2009), other international organizations have sought to more precisely specify the exact incarceration practices that might constitute cruel, inhuman and degrading treatment. In December 2007, at the International Psychological Trauma Symposium in Istanbul, for instance, 24 experts adopted the Istanbul Statement on the Use and Effects of Solitary Confinement. The statement called for using solitary confinement only under a confluence of three conditions: (1) in exceptional cases, (2) for the shortest possible period of time, and (3) as a last resort (Ayan et al. 2007). The next year, the U.N. Special Rapporteur on Torture incorporated the Istanbul Statement into an interim report on the use of solitary confinement internationally, referencing the Statement as a "a useful tool to promote the respect and protection of the rights of detainees" (Nowak 2008, p. 21).

Then, in 2011, the U.N. Special Rapporteur formally defined "prolonged solitary confinement" - a period of more than 15 days - as cruel, inhuman or degrading treatment. Beyond 15 days in solitary confinement, the Special Rapporteur argued, "some of the harmful psychological effects of isolation can become irreversible" (Méndez 2011, p. 9). And in 2015, the United Nations General Assembly unanimously adopted the Mandela Rules, a revision to the 1957 Standard Minimum Rules for the Treatment of Prisoners. The revised standards provide a clear definition of solitary confinement as "confinement of prisoners for 22 hours or more a day without meaningful human contact" and prohibit both indefinite and prolonged solitary confinement, defined as any period "in excess of 15 consecutive days" (United Nations 2015, rules 43 and 44). In sum, these statements of international human rights bodies, like the judicial decisions in courts in the United States and Europe, not only assume that solitary confinement can and should be reformed but accept that the practice has established, detrimental mental health consequences.

In the last few years, human rights monitors, politicians, and even professional associations, have amplified these calls to limit the use of solitary confinement. Following hunger strikes by tens of thousands of prisoners protesting the conditions of their long-term solitary confinement in California's Pelican Bay supermax (Reiter 2016), Amnesty International (2012) released the report The Edge of Endurance condemning California's long-term isolation facilities and policies as violations of international human rights standards. Two years later, Amnesty International (2014) released Entombed, which levied similar judgments against federal supermax facilities in the United States.

Various American professional associations have also been joining the growing ranks of solitary confinement critics. The American Public Health Association (2013) identified solitary confinement as a serious public health issue. The American Medical Association (2014) called for limitations on the use of solitary confinement in juvenile facilities to situations in which serious health or safety risks exist. The American Bar Association highlighted the dangerous effects of solitary confinement on juveniles and discouraged the widespread use of the practice in testimony to the Senate Judiciary Subcommittee on the Constitution, Civil Rights and Human Rights (Susman 2014). Federal legislators were not alone in paying close attention to solitary confinement and its harms - both potential and actual. In J anuary of 2016, President Obama issued regulations to ban solitary confinement for federal juvenile prisoners and to limit solitary confinement for adult prisoners (Obama 2016, Samuels et al. 2016).

A recent article in the J ournal of the American Academy of Psychiatry and Law called for psychiatrists to Join the Call to Abolish Solitary Confinement. The article argued for the American Psychiatric Association to take an unusually firm stance against all uses of solitary confinement, not just solitary confinement policies affecting the mentally ill or juveniles (Appelbaum 2016). Of course, the association of professional psychiatrists has not actually taken such a stance. Few other reformers - whether judicial, international human rights bodies, or professional associations - have called 
for total abolition of solitary confinement. Most of the in-depth analyses of the problems with solitary confinement - often in the form of reports and academic articles - have engaged with both the debates around solitary confinement reform and the failures of these reforms, but they have also reified categories of exclusion from solitary confinement (e.g., juveniles) and promoted limitations to the practice (e.g., fifteen days, or only in certain specified circumstances).

The history of failed attempts at solitary confinement reform, however, suggests that new reform efforts must do more to overcome the persistent resilience of the practice. This is not to say that calls for abolition of solitary confinement will necessarily be more productive than calls for reform and refinement. After all, Dickens called for the abolition of solitary confinement after he visited Eastern State Penitentiary in the 1840s, and the U.S. Supreme Court assumed abolition was in sight in 1890, even though solitary confinement was just being initiated in Colorado prison cells for those sentenced to death.

Some scholars, in fact, have recently argued for a re-framing of the assumed opposition between reform and abolition. For instance, Carlton (2016) has argued that reformist agendas linked to broader social change movements, such as those seeking increased gender, race, or class equality, have the potential to amplify the more radical and critical (non-reformist) agendas of multiple movements at once. Carlton makes this argument explicitly in the context of analyzing a campaign to improve prison conditions for women in Victoria, Australia: activists sought reformist improvements to brutal conditions of confinement, including demanding that a women's prison remain open, but linked their demands to more radical claims about the need to abolish both incarceration and discrimination against women. In an inverse analysis, describing a campaign against plans to build a new jail complex in Bloomington, Indiana, Schept (2015) notes that advocates expressed explicitly abolitionist views, but failed to involve other social movements, linked to race and class oppression, and this limited the impact of non-reformist, abolitionist campaigns. The reformist/non-reformist divide, then, is just one way to understand the limitations of prior attempts at either reforming or abolishing solitary confinement.

If anything, the failures of prior solitary confinement reform efforts suggest that there is no simple pathway to reform. Previous criticisms of solitary confinement, even when widespread, sustained, and integrated with legal reform efforts, whether in countries known for their humane prisons or in countries criticized for their abusive prisons, have failed to reduce prison systems' reliance on the practice, and to eliminate the ongoing abuses, which seem to be inevitably associated with the practice. As Justice Kennedy said (Davis v. Ayala 2015, concurrence at 2): "The human toll wrought by extended terms of isolation long has been understood, and questioned". And yet, the practice continues.

However, by more systematically analyzing the characteristics of solitary confinement that have persisted over time and across disparate geographies and socio-political structures, perhaps reformers will be able to engage more directly with both the failures of prior reforms and with the most troublesome characteristics and collateral consequences of solitary confinement policies. New human rights standards, like the Mandela Rules, have sought to integrate reform and abolition goals. Of course, reformers must continue to navigate the reformist versus nonreformist, or abolitionist, divide, while remaining attuned to complimentary social change agendas, such as elevating respect for human dignity (Simon 2014), and implementing robust procedural protections - agendas which might support alternative models of punishment. In particular, the history of solitary confinement suggests that the most vulnerable intersect with the least visible, and reforms must both reduce vulnerability and increase visibility for everyone affected by solitary confinement.

A number of recent scholarly critiques of mass incarceration more generally are also relevant in re-thinking solitary confinement reform and non-reform. For instance, 
Gottschalk (2014) has simultaneously warned against reforms targeting easily protected populations (whether the vulnerable, the sympathetic, or the non-violent) while also advocating for incremental change in the form of substantial financial investment in resolving the resource and culture inequalities at the root of mass incarceration. Likewise, addressing the abuses of solitary confinement will likely require substantial financial investments in treating the underlying mental health problems (and sometimes even sheer boredom from lack of education and employment opportunities) that land prisoners in solitary confinement in the first place.

Spade (2001), in writing about transgender treatment under the law suggests that practices and processes of reform - involving re-conceptualizing mistreatment - are as important as the specific agenda or policy outcomes reformers achieve. By analogy, the practices and processes underlying solitary confinement and the practices and processes shaping reform agendas deserve as much attention as the goals of reform versus abolition. In many cases, perhaps, reformers have asked the wrong questions. Regarding the broader history of prison reform, Rubin (forthcoming) has suggested that we stop asking why prisons fail and start asking why we expect prisons to succeed. Re-focusing on process and asking different questions seem like exactly the kinds of re-conceptualizations that will be required to escape the cycle of reform and retrenchment evident in the long history of solitary confinement use around the world.

\section{References}

Adams, J., 2001. "The wildest show in the south": tourism and incarceration at Angola. Drama Review, 45 (2), 94-108.

Ahmad v United Kingdom, 2012. Applications nos. 24027/07, 11949/08, 36742/08, 66911/09 and 67354/09 (Strasbourg: 9 Sept.).

American Medical Association, 2014. AMA Adopts New Policies to Improve Health of Nation at Interim Meeting [online]. Press release, 10 November. Available from: http://www.marketwired.com/press-release/ama-adopts-new-policiesto-improve-health-of-nation-at-interim-meeting-1966544.htm [Accessed 31 May 2017].

American Public Health Association, 2013. Solitary Confinement as a Public Health Issue [online]. Policy statement, 5 November. Available from: https://www.apha.org/policies-and-advocacy/public-health-policystatements/policy-database/2014/07/14/13/30/solitary-confinement-as-apublic-health-issue [Accessed 31 May 2017].

Amnesty International, 2012. USA: The Edge of Endurance - Prison Conditions in California's Security Housing Units. AMR 51/060/2012 [online]. London. Available from: http://www.amnestyusa.org/sites/default/files/edgeofendurancecaliforniarepor t.pdf [Accessed 31 May 2017].

Amnesty International, 2014. Entombed: Isolation in the U.S. Federal Prison System. AMR 51/040/2014 [online]. London. Available from: http://www. amnestyusa.org/sites/default/files/amr510402014en.pdf [Accessed 31 May 2017].

Appelbaum, K.L., 2016. American Psychiatry Should J oin the Call to Abolish Solitary Confinement. Journal of the American Academy of Psychiatry and Law, 43 (4), 406- 415.

Ashker v Brown. 2015. Case No.: 4:09-cv-05796-CW (N.D. Cal.).

Attorney General v Damache, 2013. 51 EXT, 2013670 JR \& 2014112 JR (High

Court of I reland, 21 May 2015). 
Ayan, A., et al., 2007. The Istanbul statement on the use and effects of solitary confinement. Adopted at the International Psychological Trauma Symposium, Istanbul [online], 9 December. Available from:

http://solitaryconfinement.org/uploads/Istanbul_expert_statement_on_sc.pdf [Accessed 31 May 2017].

Baumgartel, S., et al., 2015. Time-In-Cell: The ASCA- Liman 2014 National Survey of Administrative Segregation in Prison [online]. New Haven, CT: Arthur Liman Public Interest Program, Yale Law School, with the Association of State Correctional Administrators, 31 August. Available from: https://law.yale.edu/system/files/documents/pdf/ascaliman administrative segregation report sep_2 2015. pdf [Accessed 31 May 2017].

Beaumont, G. (de), and Tocqueville, A. (de), 1833. On the Penitentiary System in the United States and Its Application to France [online]. Trans.: F. Lieber. Philadelphia, PA: Casey, Lea \& Blanchard. Available from: http://www.archive.org/details/onpenitentiarysy00beauuoft [Accessed 31 May 2017].

Beck, A.J., 2015. Use of Restrictive Housing in U.S. Prisons and Jails, 2011-12 [online]. Special report. Washington, DC: Bureau of Justice Statistics, Government Printing Office. October. Available from: http://www.bjs.gov/content/pub/pdf/urhuspj1112.pdf [Accessed 31 May 2017].

Blatt-Herold, S., 2016. Settlement in 11-Year Lawsuit Promises Relief from Abuse for Mentally III in South Carolina's Prisons. Solitary Watch [online], 10 June. Available from: http://solitarywatch.com/2016/06/10/settlement-in-11-yearlawsuit-promises-relief-from-abuse-for-mentally-ill-in-south-carolinas-prisons/ [Accessed 31 May 2017].

Blume, J.H., Johnson, S.L., and Seeds, C., 2008. An Empirical Look at Atkins v. Virginia and Its Application in Capital Cases. Tennessee Law Review, 76, 625639.

Brown, M., 2009. The Culture of Punishment: Prison, Society, and Spectacle. New York University Press.

Brown, R.E., and Milner, P.M., 2003. The Legacy of Donald O. Hebb: More than the Hebb Synapse. Nature Reviews: Neuroscience, 4 (December), 1013-1019.

Carlton, B., 2007. Imprisoning Resistance: Life and Death in an Australian Supermax. Sydney: Institute of Criminology Press.

Carlton, B., 2016. Penal reform, anti-carceral feminist campaigns and the politics of change in women's prisons, Victoria, Australia. Punishment and Society [online], 24 November. Available from: http://journals. sagepub.com/doi/pdf/10.1177/1462474516680205 [Accessed 9 January 2018].

Champion, M.K., 2007. Commentary: Seclusion and Restraint in Corrections-A Time for Change. Journal of the American Academy of Psychiatry Law, 35 (4), 426-430.

Davis v Ayala, 135 S. Ct. 2187 (Kennedy, J., concurring) (2015), reh'g denied, 136 S. Ct. 14 (2015).

Dey, E., 2009. Prison tours as a research tool in the golden gulag. Journal of Prisoners on Prisons, 18 (1\&2), 119-125.

Dickens, C., 1842. Philadelphia and Its Solitary Prison. American Notes for General Circulation. The Literature Network [online]. Available from: 
http://www.online-literature.com/dickens/americannotes/8 [Accessed 31 May 2017].

Feeley, M.M., and Rubin, E.L., 1998. Judicial Policy Making and the Modern State: How the Courts Reformed America's Prisons. New York: Cambridge University Press.

Fellner, J., 2015. Callous and Cruel [online]. Report. New York: Human Rights Watch. Available from: https://www.hrw.org/report/2015/05/12/callous-andcruel/use-force-against-inmates-mental-disabilities-us-jails-and [Accessed 31 May 2017].

Friedman, L. M., 1993. Crime and punishment in American history. New York: BasicBooks.

Gibbons, J.J., and Katzenbach, N.D., 2006. Confronting confinement: a report of the Commission on Safety and Abuse in America's Prisons. New York: Vera Institute of Justice.

Gonnerman, J., 2014. Before the Law. The New Yorker [online], 6 October. Available from: http://www. newyorker.com/magazine/2014/10/06/beforethe-law [Accessed 31 May 2017].

Gonnerman, J., 2016. Kalief Browder Learned How to Commit Suicide on Rikers. The New Yorker [online], 2 J une. Available from:

http://www. newyorker.com/news/news-desk/kalief-browder-learned-how-tocommit-suicide-on-rikers [Accessed 31 May 2017].

Gottschalk, M., 2014. Caught: The Prison State and the Lockdown of American Politics. New Jersey: Princeton University Press.

Grassian, S., 2010. 'Fatal Flaws' in the Colorado Solitary Confinement Study. Solitary Watch [online], 15 November. Available from: http://solitarywatch.com/2010/11/15/fatal-flaws-in-the-colorado-solitaryconfinement-study/ [Accessed 31 May 2017].

Guenther, L., 2013. Solitary Confinement: Social Death and Its Afterlives. Minneapolis, MN: University of Minnesota Press.

Haney, C., and Lynch, M., 1997. Regulating prisons of the future: A psychological analysis of supermax and solitary confinement. New York University Review of Law and Social Change, 23 (4), 477-570.

Hawkley, L.C., 2015. Expert Report for Ashker v Brown (2015), Case No.: 4:09-cV05796-CW (N.D. Cal.). United States District Court, Northern District of California, Oakland division, 12 March. Available from: https://ccrjustice.org/sites/default/files/attach/2015/07/Hawkley\%20Expert\% 20Report.pdf [Accessed 31 May 2017].

Henley, J., 2016. Anders Breivik's human rights violated in prison, Norway court rules. The Guardian [online], 20 April. Available from: https://www.theguardian.com/world/2016/apr/20/anders-behring-breivikshuman-rights-violated-in-prison-norway-court-rules [Accessed 31 May 2017].

In Re Medley, 134 U.S. 160 (1890).

J ohnston, N., 2000. Forms of Constraint. A History of Prison Architecture. Chicago, IL: University of Illinois Press.

Keltner, D., 2015. Expert Report for Ashker v. Brown (2015), Case No.: 4:09-cv05796-CW (N.D. Cal.). United States District Court, Northern District of California, Oakland division, 11 March. Available from: https://ccrjustice.org/sites/default/files/attach/2015/07/Keltner\%20Expert\%2 OReport.pdf [Accessed 31 May 2017]. 
Lieberman, M.D., 2015. Expert Report for Ashker v. Brown (2015), Case No.: 4:09CV-05796-CW (N.D. Cal.). United States District Court, Northern District of California, Oakland division, 11 March. Available from: https://ccrjustice.org/sites/default/files/attach/2015/07/Lieberman\%20Expert \%20Report.pdf [Accessed 31 May 2017].

Madrid v Gomez, Case No. 90-3094, 899 F. Supp 1146 (N.D. Cal. 1995).

Mathiesen, T., 1974/2014. The Politics of Abolition of Revisited. New York: Routledge.

McCaffrey, S.C., 2013. There's a Whole World Out There: Justice Kennedy's Use of International Sources. McGeorge Law Review, 44 (1), 201-10.

Méndez, J.E., 2011. Torture and other cruel, inhuman or degrading treatment or punishment [online]. Interim report of the Special Rapporteur of the Human Rights Council. United Nations General Assembly, 66 ${ }^{\text {th }}$ Session, Item 69(b), A/66/268, 5 August. Available from:

http://solitaryconfinement.org/uploads/SpecRapTortureAug2011.pdf [Accessed 31 May 2017].

Nowak, M., 2008. Torture and other cruel, inhuman or degrading treatment or punishment [online]. Interim report of the Special Rapporteur of the Human Rights Council. United Nations General Assembly, 63 ${ }^{\text {rd }}$ Session, A/63/175, 28 July. Available from: http://www.refworld.org/docid/48db99e82.html [Accessed 31 May 2017].

O'Donnell, I., 2014. Prisoners, Solitude and Time. Oxford University Press.

O'Hearn, D., 2013. Diaspora of Practice: Northern Irish Imprisonment and the Transnational Rise of Cellular Isolation. Breac: A Digital J ournal of Irish Studies [online], 12 April. Available from:

https://breac.nd.edu/articles/diaspora-of-practice-northern-irishimprisonment-and-the-transnational-rise-of-cellular-isolation/ [Accessed 31 May 2017].

O'Keefe, M.L., et al., 2011. One Year Longitudinal Study of the Psychological Effects of Administrative Segregation [online]. Colorado Department of Corrections and University of Colorado. Document No. 232973. Washington, D.C.: National Criminal J ustice Research Service, National Institute of J ustice. Available from: https://www.ncjrs.gov/pdffiles1/nij/grants/232973.pdf [Accessed 31 May 2017].

Obama, B., 2016. Why we must re-think solitary confinement. The Washington Post [online], 25 J anuary. Available from:

https://www. washingtonpost.com/opinions/barack-obama-why-we-mustrethink-solitary-confinement/2016/01/25/29a361f2-c384-11e5-89650607e0e265ce story.html [Accessed 31 May 2017].

Odier, P., 1982. The rock: A history of the fort/the prison. Eagle Rock, CA: L'Image Odier.

Peoples v Fischer, Index No. 11 CIV 2964 SAS (S.D.N.Y. 2016).

Piché, J., and Walby, K., 2010. Problematizing Carceral Tours. British J ournal of Criminology, 50 (3), 570-581.

Piché, J., and Walby, K., 2012. Carceral Tours and the Need for Reflexivity: A Response to Wilson, Spina and Canaan. The Howard J ournal of Criminal Justice, 51 (4), 411-418.

Pifer, N., 2016. The Scientific and the Social in Implementing Atkins V. Virginia. Law and Social Inquiry, 41 (4), 1036-1060. 
Press, E., 2016. Madness. The New Yorker [online], 2 May. Available from: http://www. newyorker.com/magazine/2016/05/02/the-torturing-of-mentallyill-prisoners [Accessed 31 May 2017].

Rakia, R., 2015. Rikers Is Reforming Solitary Confinement-With More Solitary Confinement? The Nation [online], 10 November. Available from: http://www. thenation.com/article/rikers-is-reforming-solitary-confinementwith-more-solitary-confinement/ [Accessed 31 May 2017].

Reiter, K., 2012. The Most Restrictive Alternative: A Litigation History of Solitary Confinement in U.S. Prisons, 1960-2006. Studies in Law, Politics and Society, 57, 69- 123.

Reiter, K., 2014. Punitive Contrasts: United States vs. Denmark - A Socio-Legal Comparison of Two Prison Systems. In: L. Sullivan, ed., The Criminal Justice and Law Enforcement Annual: Global Perspectives. Brooklyn, NY: AMS Press, Inc., 139-176.

Reiter, K., 2016. 23/7: Pelican Bay Prison and the Rise of Long-term Solitary Confinement. New Haven, CT: Yale University Press.

Reiter, K., and Blair, T., 2015. Punishing Mental Illness: Trans-institutionalization and Solitary Confinement in the United States. In: K. Reiter and A. Koenig, eds., Extreme Punishment: Comparative Studies in Detention, Incarceration, and Solitary Confinement. New York: Palgrave MacMillan, 177-196.

Reiter, K., and Koenig, A., eds., 2015. Extreme Punishment: Comparative Studies in Detention, Incarceration and Solitary Confinement. New York: Palgrave MacMillan.

Reiter, K., Sexton, L., and Sumner, J., 2017. Negotiating Imperfect Humanity in the Danish Penal System. In: P.S. Smith and T. Ugelvik, eds., Embraced by the welfare state? Scandinavian penal history, culture and prison practice. New York: Palgrave MacMillan, 481-508.

Ross, J.I., 2013. The Globalization of Supermax Prisons. New Brunswick, NJ : Rutgers University Press.

Rubin, A., 2015. A Neo-Institutional Account of Prison Diffusion. Law \& Society Review, 49 (2), 365-399.

Rubin, A., and Reiter, K., 2017. Continuity in the Face of Penal Innovation: Revisiting the History of American Solitary Confinement. Law and Social Inquiry [online], 5 November. Available from: http://onlinelibrary.wiley.com/doi/10.1111/Isi.12330/full [Accessed 10 January 2018].

Rubin, A., forthcoming. The Birth of the Penal Organization: Why Prisons Were Born to Fail. In: J. Simon, H. Aviram and R. Greenspan, eds., The Legal Process and the Promise of J ustice: Studies Inspired by the Work of Malcolm Feeley. New York: Cambridge University Press.

Rytter, T., 2015. DIGNITY speaks to the UN Committee Against Torture [online]. News. 13 November. Copenhagen, Denmark: DIGNITY, Danish Institute Against Torture. Available from: https://dignityinstitute.org/news-andevents/news/2015/dignity-presents-report-on-denmark-before-the-uncommittee-against-torture/ dignity-speeks-to-the-un-committee-againsttorture/ [Accessed 31 May 2017].

Samuels, C.E., et al., 2016. Report and Recommendations Concerning the Use of Restrictive Housing [online]. Final report. U.S. Department of J ustice, January. Available from: https://www.justice.gov/dag/file/815551/download [Accessed 31 May 2017]. 
Schept, J., 2015. Progressive Punishment: Job Loss, Jail Growth, and the Neoliberal Logic of Carceral Expansion. New York University Press.

Shames, A., Wilcox, J., and Subramanian, R., 2015. Solitary Confinement: Common Misconceptions and Emerging Safe Alternatives [online]. New York: Vera Institute of J ustice, Center on Sentencing and Corrections: The Robert W. Wilson Charitable Trust Series. May. Available from:

https://storage.googleapis.com/vera-webassets/downloads/Publications/solitary-confinement-common-misconceptionsand-emerging-safe-alternatives/legacy downloads/solitary-confinementmisconceptions-safe-alternatives-report_1.pdf [Accessed 9 J anuary 2018].

Silverstein v Federal Bureau of Prisons, No. 12-1450, D.Ct. No. 1:07-CV-02471PAB-KMT (10th Cir. May 22, 2014).

Simon, J., 2014. Mass Incarceration on Trial: A Remarkable Court Decision and the Future of Prisons in America. New York: The New Press.

Smith, P.S., 2009. Solitary Confinement - History, Practice, and Human Rights Standards. Prison Service J ournal, 181 (special issue), 3-11.

Smith, P.S., 2011. A Critical look at Scandinavian Exceptionalism: Welfare State theories, Penal Populism, and Prison Conditions in Denmark and Scandinavia. In: T. Ugelvik and J. Dullum, eds., Nordic prison practice and policy exceptional or not?: Exploring penal exceptionalism in the Nordic context. New York: Routledge.

Smith, P.S., 2017. Punishment without sentence? Scandinavian pre-trial practices and the power of the "benevolent" state. In: P.S. Smith and T. Ugelvik, eds., Embraced by the welfare state? Scandinavian penal history, culture and prison practice. New York: Palgrave MacMillan.

Spade, D., 2001. Normal Life: Administrative Violence, Critical Trans Politics, and the Limits of Law. Brooklyn, NY: South End Press.

Susman, T.M., 2014. Statement of the American Bar Association before the Senate Judiciary Subcommittee of the American Bar Association before the Senate Judiciary Subcommittee on the Constitution, Civil Rights, and Human Rights for the hearing on "Reassessing Solitary Confinement II: The human rights, fiscal, and public safety consequences for the Hearing Record" [online]. Available from:

http://www. americanbar.org/content/dam/aba/uncategorized/GAO/2014feb25 _solitaryconfinements_t.authcheckdam.pdf [Accessed 31 May 2017].

United Nations General Assembly, 2016. United Nations Standard Minimum Rules for the Treatment of Prisoners (the Nelson Mandela Rules). (A/RES/70/175) [online]. Resolution adopted by the UN General Assembly on 17 December 2015 on the report of the Third Committee (A/70/490). Available from: https://www.penalreform.org/wp-content/uploads/1957/06/ENG.pdf [Accessed 9 January 2018]. 